\title{
Competitive Strategies and Performance of Commercial Banks in Mombasa County, Kenya
}

\author{
Nyachwaya Joseph Mariga ${ }^{1} \&$ James Maina Rugami ${ }^{2}$ \\ ${ }^{1}$ Correspondent Author, School of Business, Kenyatta University, Kenya \\ ${ }^{2}$ Lecturer, School of Business, Kenyatta University, Kenya
}

\begin{abstract}
Commercial banks in Kenya and especially Mombasa County are facing firm rivalry demanding the use of competitive strategies so as to improve their performance. Most of the commercial banks are deliberating on ways to enhance their performance, with competitive strategies being one of them to arrive a market and afterwards make sense of and ensure its aggressive position. Therefore, this study aimed at establishing the effect of competitive strategies on the performance of commercial banks in Mombasa County. The specific objectives were to determine the effect of cost leadership strategy, differentiation strategy and focus strategy on the performance of commercial banks in Mombasa County. The study was anchored on the theory of resource-based view, strategic balancing and game theory. A descriptive research design was employed in this study. The target population of this study was 280 commercial banks staff in Mombasa County. The sample size was eighty-four after adopting a stratified random sampling technique to select $30 \%$ of the target population. The study made use of primary data collection using questionnaires. The data was analyzed using the Statistical Package for Social Sciences (SPSS) Version 24.0 and presented using tables. The study established that despite the challenges in implementation, competitive strategies are very important for banks to remain competitive in the market. The study further concluded that understanding the market structure is a key determinant for the successful implementation of competitive strategies. Banks following a cost leadership strategy realize statistically significant superior performance compared to those that pursue broad differentiation and focus strategy which reports above-average returns. The researcher highly recommends that commercial banks consider shifting more of their focus on the cost leadership strategy in order to realize superior performance. To succeed at offering the lowest price while still achieving profitability and a high return on investment, commercial banks are recommended to operate at a lower cost than its rivals, this could be possible through some fairly unique capabilities to achieve and sustain their low-cost position. The study also recommends strategy planners to integrate and embrace the differentiation strategy which will enable them to differentiate in various methods such as new technology, brand image, design, network customer service or the number of features. Further, commercial banks are recommended to centre on the existing markets and products or services; they can create competitive edge by getting the best mix between existing products and existing markets.
\end{abstract}

Key Words: Cost Leadership Strategy, Differentiation Strategy, Focus Strategy, Competitive Strategies, Performance of Commercial Banks in Mombasa County

DOI: $10.35942 /$ jbmed.v2i1.109

\section{Cite this Article:}

Nyachwaya, J., \& Rugami, J. (2020). Competitive Strategies and Performance of Commercial Banks in Mombasa County, Kenya. International Journal of Business Management, Entrepreneurship and Innovation, 2(1), 65-74. https://doi.org/10.35942/jbmed.v2i1.109 
International Journal of Business Management, Entrepreneurship and Innovation, Volume 2, Issue 1, 2020, PP 65-74, ISSN 2707-8027

\section{IIJCAB}

\section{Introduction}

For financial development and improvement in any industry, effective and reasonable markets are fundamental (Lewis, 2011). The last two decades have seen liberalization which has prompted hardened rivalry in numerous divisions of the economy and has rolled out firm's improvement by taking certain activities with a specific end goal to survive (Amit \& Schoemaker, 2013). This drastically heightened the competition being faced by organizations making it hard for them to remain profitable. The competition has affected banks in Kenya and they have had to create strategies to react to rivalry, protect their niche and to enlarge their market share of the overall industry. To this end, commercial banks have been occupied with extension as a vital growth choice which is especially important in developing nations due to low product entrance and utilization levels (Odunayo, 2018). In a nation where the budgetary segment is overwhelmed by business banks, any disappointment in the area has massive ramifications on the financial development of the nation. This is because of the way that any liquidation that could occur in the segment has a severe impact that can prompt bank runs, emergencies and bring generally speaking money related emergency and financial tribulations. Regardless of the great generally speaking money related execution of banks in Kenya, there are two or three banks announcing misfortunes (Oloo, 2011). The unparalleled growth in banks is as a result of changes from an environmental and regulatory perspective. These changes forced foreign banks to incorporate in other countries which included setting up branches or subsidiaries in Africa (Ebimobowei, 2012). The need for study on competitive strategies and their effect on the performance of commercial banks in Mombasa County cannot be ignored. Though several articles relating to competitive strategies have been analysed no conclusive finding has been established which necessitated this study. To understand the competitiveness of these banks is imperative in improving the performance of the banking industry in Kenya that has been dwindling in the recent past.

\section{Statement of the Problem}

Firms work inside a domain that impacts its tasks either emphatically or contrarily unfavourably depending upon the possibility of its business (Finneran, 2011). Specifically, commercial banks situated in Kenya are understanding that firm challenge inside the financial business requests the plan of aggressive techniques to ensure their execution. Also, Maxine (2012) observed commercial banks in Mombasa County though being major players in the Kenyan banking industry are facing many challenges from the environment and its competitors. These banks have faced challenges growing customer and overall business base while some of the banks want to offload their stakes. Several studies have been done with respect to competitive strategies. Mohsen (2015) showed that competitive strategies mediate the effect of production capability and export performance. Ashok and Kalinga (2017) established that strategy formulation, more particularly differentiation was the key driver of firm performance in the Oil and Gas Industry. Waidi (2018) concluded that there is a relationship between competitive strategies, its constituents and performance of telecommunication companies. Locally, Obado (2017) found that commercial banks utilized cost authority and differentiation as the principal procedures. Ngandu (2014) demonstrated that the methodology with the most grounded effect on the execution of lodgings is differentiation system. Further, Gathinji (2014) revealed that competition is high in the industry and product differentiation and low cost leadership are the most commonly used strategies. Guided by these actualities, there is a need, to plan an investigation on banking segment in Mombasa County, explicitly to comprehend the effects of combined strategies in commercial banks of Mombasa County. Also, data from the above studies show that there is a gap in the analysis of the effect on competitive strategy on performance in commercial banks in Mombasa County. This study aimed to address this 
International Journal of Business Management, Entrepreneurship and Innovation, Volume 2, Issue 1, 2020, PP 65-74, ISSN 2707-8027

\section{[IJCAB}

research gap and sought to establish the competitive strategies employed by commercial banks in Mombasa County and what effect they have on their performance.

\section{Objectives}

The study was guided by the following specific research objectives:

i. To establish the effect of cost leadership strategy on the performance of commercial banks in Mombasa County.

ii. To determine the effect of differentiation strategy on the performance of commercial banks in Mombasa County.

iii. To establish the effect of focus strategy on the performance of commercial banks in Mombasa County.

\section{Literature Review}

\subsection{Theoretical Review}

The study was guided by resource based theory. Resource-based view theory was used to set the basis of this study and it involves a rising and overwhelming zone of the strategy literature which tends to the subject of an association character and it is basically stressed with the source and nature of essential limits (Raynor, 2007). The asset-based point of view has an intraauthoritative fixation and battles that execution is an outcome of firm-specific resources and capacities. The reason of the advantage based view is that powerful firms found their future forcefulness on the improvement of unquestionable and fascinating capacities, which may every now and again be sure or intangible in nature (McGahan, 2007). The resource-based view (RBV) dissect and decipher assets of the organizations to see how organizations accomplish maintainable competitive advantage (Barney, 1991). This theory was significant to the examination since it tends to the critical request of why firms are extraordinary and how firms achieve and proceed with the high ground by sending their advantages. As indicated by Madhani (2009), performance vacillation between firms depends on upon its responsibility for thoughtful information sources and capacities. The theory, therefore, supports the cost leadership strategy by indicating how assets are the firm-explicit resources valuable for making a cost favourable position and that couple of contenders can procure effectively.

Theory of strategic balancing imperative was also used. The theory is built upon the reason that the technique of an association is for the most part essentially indistinguishable to the system of an individual. Emphatically, the execution of association is impacted by the performing specialists direct, for instance, the course of action of pioneers' characteristics (Collins et al., 2009). An association vacillates between various contradicting shafts that suggest cooperation and contention. This considers nearness of various setups of associations that disappear just if the association together swings toward a standard of posts of experience. Key changing is contained three models which include: social, amicable and association models. The association would then be able to substitute in grasping the two frameworks so as to keep their relationship balanced. There are three sorts of focused associations: contention directed, investment controlled, and approach associations. The Theory of Strategic Balancing thus provides basis on which the study of the effect of differentiation strategy on the banking industry in Mombasa County was understood. The different opinions held by the proponents of the theory enriched the study by giving it a more integrated approach in evaluating the differentiation strategy.

Game theory also guided the study. The scientific game theory was developed by Deschamps and Nayak (2008). Game theory is the investigation of the routes in which vital collaborations among judicious players create results as for the inclinations (or utilities) of those players, none 
International Journal of Business Management, Entrepreneurship and Innovation, Volume 2, Issue 1, 2020, PP 65-74, ISSN 2707-8027

\section{[IJCAB}

of which may have been proposed by any of them. Game theorists, similar to financial specialists and logicians contemplating level headed basic leadership, depict these by method for a conceptual idea called utility. This alludes to the measure of welfare an agent gets from an objector or an event. Welfare alludes to some regulating list of relative prosperity, legitimized by reference to some foundation structure. On account of individuals, it is most average in financial aspects and uses of game theory to assess their relative welfare by reference to their own particular understood (Mintzberg, 1973). The theory is of importance as it attempts to coordinate the focused procedures as vital connections and how this prompted to definitive consequences for the execution of the business saves money with particular enthusiasm on a piece of the overall industry, benefit and development. Therefore the theory supported the use of third objective, 'focus strategy and its effect on the performance of commercial banks.

\subsection{Empirical Literature Review}

Munyiri (2014) examined focused methodologies and client maintenance among business banks in Kenya. The investigation was led on all enlisted business banks in Kenya with cost administration, differentiation and focus being utilized as the factors. The investigation found a critical connection between cost administration procedures and client maintenance. The discoveries demonstrated that cost authority system encourages the bank to increase the upper hand by lessening financial expenses underneath contenders. The examination additionally demonstrated that cost initiative offers a wide market for different administrations. Gathinji (2014) conducted a study on the relationship between competitive strategies and organizational performance among firms in the mobile telecommunications industry in Kenya. The study identified the competitive strategies adopted by firms in the industry in Kenya, assessed the different levels of implementation of competitive strategies within the firms and examined the relationship between these strategies and firm performance. The study revealed that competition is high in the industry and product differentiation and low cost leadership are the most commonly used strategies. Nyauncho and Nyamweya (2015) did an investigation on the effects of cost leadership strategy on performance of Liquefied Petroleum Gas Companies (LPGC) in Eldoret town. The study used questionnaires and interview schedule as data collection instruments. Data analysis was carried out using descriptive statistics such as Spearman rank coloration, means. The study concluded that, cost leadership influences the performance of LPGCs performance enabling the company to reduce price leading to high volume of sales visa a-visa profit margin, increase in service delivery, less return inwards, reduced operational costs and reduced wastages.

Manjeet, Patle and Gaurav (2016) investigated the impact of competitive differentiation strategy on firm's performance and the mediating role of quality management (QM) amongst Indian firms. A field study using questionnaire method was conducted on micro, small and medium enterprises (MSMEs) operating in various sectors namely mechanical, automobile component, electrical and electronics, and textile. Study results found no direct relationship between differentiation strategy and firm performances, but, QM entirely mediated their relationship. Empirical results concluded that design and development and information and analysis are the two components of QM which are successful in mediating the relationship between differentiation competitive strategy and firm performance. Nolega, Oloko, Sakataka, Oteki, (2015) carried out a study on the effects of product differentiation strategies on firm product performance at Kenya Seed Company (KSC), Kitale. The findings indicated that the customer's trend has grown tremendously over the last 15 years which is reflected by the growth in agent's base too due to their differentia on strategy. ASK shows provide the most important marketing strategy for KSC. The research recommends that KSC to increase market penetration by increasing agents and enhancing field days in the remote ASAL and highland areas which still plant indigenous maize seeds. Kungu (2014) did an examination on an evaluation of the viability 


\section{[IJCAB}

of the aggressive systems by business banks: An instance of Equity Bank. In view of the discoveries of his investigation, business banks in Kenya apply distinctive procedures to be aggressive. These incorporate giving items and administrations at a most reduced cost, differentiation of items and concentrating on the certain market fragment. Also, the investigation confirmed that there are two wellsprings of aggressive powers which were predominantly outer and included battles for a piece of the overall industry and quality client administrations.

Shaohan (2015) carried out a study on the importance of customer focus for organizational performance among Chinese companies. The findings of the study indicate that organizational customer orientation affects customer relationship practices, which subsequently influence production performance and customer satisfaction. Production performance and customer satisfaction lead to financial performance. Nwokah and Maclayton (2016) carried out a study on the effect of customer- focus and business performance: the study of food and beverages organizations in Nigeria. The findings of the study did not find any strong association between customer- focus and business performance in the Nigerian context using the food and beverages organizations for the study. The reasons underlying the weak relationship between customerfocus and business performance of the food and beverages organizations are government policies, new product development, diversification, innovation and devaluation of the Nigerian currency. One important finding of this study is that customer-focus leads to business performance through some moderating variables. Odunayo (2018) investigated the relationship between market focus strategy and organizational performance of telecommunication companies in Port Harcourt. The study used a cross sectional design involving management staff of 4 telecommunication companies in Port Harcourt. The population was 134 and a sample size of 100 was obtained through the Taro Yamane formula for sample size determination with the simple random technique used. After data cleaning, only data of 93 respondents were finally used for data analysis. The study concluded that market focus strategy bears a positive and significant influence on firm competitiveness.

\section{Conceptual Framework}

The conceptual framework of this study as shown by Figure 1 indicate competitive strategies as the independent variables while organizational performance is the dependent variable for the study.

\section{Independent Variables}

Dependent Variable

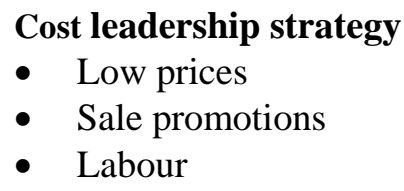

- Low prices

- Sale promotions

- Labour

Differentiation strategy

- Unique products

- Product design

- Innovation (new products)

Focus Strategy

- Market segment

- Geographical market

- Specialty

Figure 1: Conceptual Framework 
International Journal of Business Management, Entrepreneurship and Innovation, Volume 2, Issue 1, 2020, PP 65-74, ISSN 2707-8027

\section{[IJCAB}

\section{Research Methodology}

This study used descriptive survey design. The basic idea behind survey design is to measure variables by asking people questions and then examines relationships among the variables (Mugenda \& Mugenda, 2008). The target population was 280 commercial banks staff in Mombasa County. Stratified random sampling was used by the researcher to select $30 \%$ of the target population. The sample size of this study was therefore, be 84 respondents. Primary sources of data were used in data collection. The primary data was collected from the banking staff utilizing self-managed polls. The researcher directed a pilot test to test the dependability and the legitimacy of the instrument. Prior to analysis, the data was checked for completeness, accuracy, errors in responses, omissions and other inconsistencies. The data was then coded using numerals in order to put them in relevant number of categories. The data was analyzed using the Statistical Package for Social Sciences (SPSS) Version 24 and presented in the report in the form of tables and figures. Multiple regression analysis was done to establish the relationship between the variable in the study. The model was as follows; $Y=\alpha+\beta_{1} X_{1}+$ $\beta_{2} X_{2}+\beta_{3} X_{3}+\varepsilon$ where: $\mathrm{Y}$ is Performance of commercial banks in Mombasa County, $\mathrm{X}_{1}$ is cost leadership strategy, $X_{2}$ is differentiation strategy, $X_{3}$ is focus strategy, $\varepsilon$ is error term is constant term and $\beta_{1}$, to $\beta_{3}$ are Coefficients of determination of the independent variables.

\section{Research Findings and Discussion}

Regression analysis was used to establish the relationship that exists between the research variables. Table 5 shows summary of the regression model obtained.

Table 1: Model Summary

\begin{tabular}{|l|l|l|l|l|}
\hline Model & R & R Square & Adjusted R Square & Std. Error of the Estimate \\
\hline 1 & 0.729 & 0.532 & 0.569 & .37489 \\
\hline
\end{tabular}

Source: Survey Data (2019)

As shown, the model had an average adjusted coefficient of determination $\left(\mathrm{R}^{2}\right)$ of 0.532 and which implied that $53.2 \%$ on the variations the bank performance is explained by the independent variables understudy (differentiation strategy, lower interest rate, focus strategy, human resource base, internal bank resources). The result suggested that there exist a relationship between competitive strategies and performance exhibit with $(\mathrm{R})$ of 0.729 . In addition, there exists a positive relationship between competitive strategies and performance meaning increased strategies lead to increased performance. These findings agree with the studies by Datta (2009), Munyiri (2014), Gathinji's (2014), Aliqah (2012), Nolega et al., (2015) and Kungu (2014)which revealed that there was a positive and significant relationship between cost leadership strategy, differentiation strategy and focus strategy and organizational performance.

Table 2: Coefficients of Determination

\begin{tabular}{|l|c|c|c|c|c|}
\hline \multirow{2}{*}{ Model } & \multicolumn{2}{|c|}{$\begin{array}{c}\text { Unstandardized } \\
\text { Coefficients }\end{array}$} & $\begin{array}{c}\text { Standardized } \\
\text { Coefficients }\end{array}$ & \multirow{2}{*}{ T } & Sig. \\
\cline { 2 - 7 } & $\mathbf{B}$ & $\begin{array}{c}\text { Std. } \\
\text { Error }\end{array}$ & Beta & & \\
\hline (Constant) & -2.284 & 0.236 & & 3.790 & 0.015 \\
\hline $\begin{array}{l}\text { Cost leadership } \\
\text { Strategy }\end{array}$ & 0.450 & 0.119 & 0.410 & 3.616 & 0.000 \\
\hline Differentiation Strategy & 2.546 & 0.151 & 0.527 & 3.734 & 0.021 \\
\hline Focus Strategy & 0.351 & 0.094 & 0.326 & & \\
\hline
\end{tabular}

Source: Survey Data (2019) 
International Journal of Business Management, Entrepreneurship and Innovation, Volume 2, Issue 1, 2020, PP 65-74, ISSN 2707-8027

\section{[JCAB}

From the regression model coefficients results obtained as shown by Table 6 , the predictive

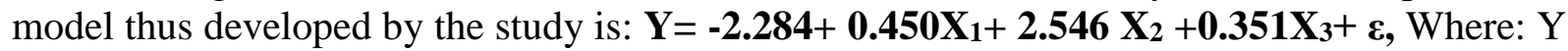
is performance of commercial banks in Mombasa County, $\mathrm{X}_{1}$ is cost leadership strategy, $\mathrm{X}_{2}$ is differentiation strategy, $X_{3}$ is focus strategy and $\boldsymbol{\varepsilon}$ is error term is constant term. From this regression model, if a unit change of a variable is tested holding the other variables constant, the results are as follows: the study revealed that a unit change in Cost leadership strategy, Differentiation strategy applied would change the bank competitiveness by a factor of 2.546, a change in unit of lower interest cost would change the bank competitiveness by a factor of 0.450 , a unit change in focus strategy would change the bank competitiveness by a factor of 0.351 . The analysis was undertaken at a 5\% significance level. The criteria for comparing whether the predictor variables were significant in the model was through comparing the obtained probability value and $\alpha=0.05$. If the probability value was less than $\alpha$, then the predictor variable was significant otherwise it wasn't. All the predictor variables were significant in the model as their probability values were less than $\alpha=0.05$.

Findings from this study showed that a low-cost leadership strategy as an independent variable recorded the highest mean of 3.19 with a standard deviation of 0.547 . Differentiation strategy was second with a mean of 2.85 and a standard deviation of 0.662 . Finally, focus strategy was least recording a mean of 2.76 with a standard deviation of 0.643 . The study also established that correlation between competitive strategies and firm performance indicators that recorded a significant strong positive relationship. This is explained by Nwokah and Maclayton (2016) who posits that the reasons underlying the weak relationship between competitive strategies and business performance are government policies, new product development, diversification, innovation and devaluation. The strength of influence that each of the independent variables had on the dependent variable was determined by the use of multiple regression coefficients of the independent variables whose results show that low-cost leadership strategy had the strongest significant influence on firm performance with a standardized beta of 0.389 . Indicating that for a unit increase in this strategy, an organization is likely to improve its performance by 39 percent. Differentiation strategy had a significant effect of 2.546 while focus strategy had 0.351 .

\section{Conclusions}

The study concluded that the sampled commercial banks gained a competitive advantage over its rivals, by providing comparable value to the customer, performing activities more efficiently than its competitors (lower cost), or performing activities in a unique way that creates greater buyer value and commands a premium price (differentiation). The study also concluded that commercial banks embrace focus strategy by laying their focus on a type of market or population in order to keep the competition steady. The study thus concludes that strategies are essential for the effective functioning of any organization. The strategic direction is realized through the ability to evaluate strategies used and achieve competitive advantage than the competitors. From the summary of the findings, the commercial bank's profitability measures respond more positively to the increases in competitive strategies that are cost driven as opposed to product and focus frameworks. Commercial banks following a cost leadership strategy realized statistically significant superior performance as compared to those that pursued broad differentiation, customer service differentiation and focus strategy that reported above-average returns. The results revealed that a larger return to equity and return to asset ratios lead to more profit margins with well calculated competitive strategies. The study therefore study concludes that the competitive strategies are relevant in the context of commercial banks' performance. 
International Journal of Business Management, Entrepreneurship and Innovation, Volume 2, Issue 1, 2020, PP 65-74, ISSN 2707-8027

\section{[IJCAB}

\section{Recommendations}

There is need for the banks to engage in a higher level of business intelligence to enable them gather relevant information from the market and benchmark it with best-known world practices to enable it to gain sustainable competitive advantage. The study highly recommends that commercial banks consider shifting more of their focus to the cost leadership strategy. Mass production, mass distribution, economies of scale, technical and product design, input cost and capacity utilization of resources are areas where the cost leadership strategy can be pursued. Commercial banks should consider offering their products to customers at minimal or even zero costs and scrap off the minimum balance requirement to open or to run an account. The study recommends that commercial banks consider shifting more of their focus to the cost leadership strategies it has to appeal to cost-conscious or price-sensitive customers, this can be achieved by having the lowest prices in the target market segment. To succeed at offering the lowest price while still achieving profitability and a high return on investment, commercial banks are recommended to operate at a lower cost than its rivals, this could be possible through some fairly unique capabilities to achieve and sustain their low-cost position. Commercial banks should as well consider offering their products to customers at minimal or even zero costs and scrap off the minimum balance requirement to open or to run an account. It is necessary for strategy planners to integrate and embrace the differentiation strategy. This will enable them to differentiate in various methods such as new technology, brand image, design, network customer service or the number of features. Commercial banks should further center on the existing markets and products or services; they can create competitive edge by getting the best mix between existing products and existing markets. This can be mainly done through product niche and market identification.

\section{REFERENCES}

Aliqah, N. Z. (2011). Empirical evidence between differentiation strategy and organization firm performance among Jordanian manufacturing firms. Asian Journal of Management Research 2(1), 61-73.

Amit, R. \& Schoemaker, J. H. (2013). Strategic Assets and Organizational Rent. Strategic Management Journal, 14(1), 33-46

Ashok, S. \& Kalinga, O., (2017). Competitive advantage and performance: An analysis of Indian Downstream Oil and Gas Industry. Academy of Accounting and Financial Studies Journal, 1(1), 22-29

Barney, J. B. (1991). Firm Resources and Sustained Competitive Advantage, Journal of Management, (17)1, 99-120.

Collins E. K., Pimtong, T., Hanqin Q. Z., \& Skitmore, R. A. (2009). Risk, Return, and Arbitrage, in I. Friend and J. Bicksler, eds., Risk and Return in Finance. Cambridge, MA: Ballinger Publishing Company.

Datta, N. (2009). The Decline of America's Soft Power in the United Nations. International Studies Perspectives, 10: 265-284.

Deschamps and Nayak (2008). Game theory, International Journal of Academic Research, 3(1), 861-868

Ebimobowei (2012). Customers' Service Strategy and Commercial Banks Survival in a PostConsolidation Era in Nigeria.

Finneran, J. (2011). Bank Efficiency with Care. www.fool.com/investing/dividend, 19th June 2012.

Gathinji, T. (2014). Credit scoring Model Using Soft Computing Methods: A Survey. International Arab Journal of Information and Technology, 7(2), 115-123.

Kungu (2014). Assessment of the Effectiveness of Competitive Strategies by Commercial Banks: Case of Equity Bank. Unpublished MBA Project. 
International Journal of Business Management, Entrepreneurship and Innovation, Volume 2, Issue 1, 2020, PP 65-74, ISSN 2707-8027

\section{[IJCAB}

Lewis, W. (2011). The Power of Productivity. USA: University of Chicago Press.

Madhani, J. (2009). Impact of Competitive Strategies on the Financial Performance of Cfc Stanbic Bank Limited. Unpublished MBA thesis. University of Nairobi

Manjeet K., Patle B. K., \& Gaurav S. (2016).The Relationship between Differentiation Strategy and Firm Performance: a Mediating Role of Quality Management, Journal of Mechanical and Civil Engineering, 22(78), 66-71

Maxine, S. (2012). Marketing-orientated pricing: Understanding and applying factors that discriminate between successful high and low price strategies. European Journal of Marketing, 46(11), 1647-1670.

McGahan, B. (2007). Blending "we/me" in Performance Management. Team Performance Management, 9 (7/8).

Mintzberg, P. (1973). The effect of competitive strategies and organizational structure on hotel performance, International Journal of Contemporary Hospitality Management, 24(1), $140-159$

Mohsenzadeh, M., \& Ahmadian, S. (2016). The mediating role of competitive strategies in the effect of firm competencies and export performance. Procedia Economics and Finance, $36,456-466$.

Mugenda, O. M., \& Mugenda, A. G. (2008). Research methods. Nairobi: ACTS.

Munyiri, L. (2014). Competitive strategies and customer retention among commercial banks in Kenya. Unpublished MBA Project, University of Nairobi.

Mutunga, S. L. \& Minja, D. (2014). Generic strategies employed by food and beverage firms in Kenya and their effects on sustainable competitive advantage. International Journal of Business and Management Review. 2(6), 1-15.

Ngandu, O. A. (2014). The Impact of Risk Pricing on Profit Maximization of Insurance Companies, International Journal of Academic Research in Economics and Management Sciences, 1(4), 2226-3624

Nolega, J., Oloko, M., Sakataka, K., \& Oteki, O. (2015). The effects of product differentiation strategies on firm product performance at Kenya Seed Company (KSC), Kitale. Unpublished MBA Project.

Nwokah K., \& Maclayton M. (2016). The effect of customer-focus and business performance. Unpublished MBA Project

Nyauncho M. J., \& Nyamweya I. N. (2015). Assessment of the effect of Cost Leadership Strategy on the performance of Liquefied Petroleum Gas Companies in Eldoret town, Uasin Gishu County, Kenya. International Journal of Business and Management Invention, 4(4), 1-7

Obado, C. L. (2017). Performance of Banking Industry in Kenya: A Study of KCB Bank Kenya Limited (Doctoral dissertation, United States International University-Africa).

Odunayo O. A. (2018). Market Focus Strategy And Organizational Performance Of Telecommunication Companies In Port Harcourt, International Journal of Innovative Research and Advanced Studies (IJIRAS), 5(3), 2394-4404

Oloo, O. (2011). Banking Survey Report, The best banks this decade 2001-2010, Think Business Limited, Kenya, 10-12.

Olson and Slater (2015). The balanced scorecard, competitive strategy, and performance. Academy of Management Journal, 44(2), 292-303.

Raynor, D. (2007). What Are the Competitive strategies of Supermarkets? Retrieved from Azcentral:http://yourbusiness.azcentral.com/pricing-strategies-supermarkets.

Shaohan L. (2015). The importance of customer focus for organizational performance among Chinese companies. Asian Management Journal, 19(3), 317-331 
International Journal of Business Management, Entrepreneurship and Innovation, Volume 2, Issue 1, 2020, PP 65-74, ISSN 2707-8027

[IJCAB

Wadi, R. (2018). Using competitive advantage theory to analyze IT sectors in developing countries: a software industry case analysis. Information Technologies \& International Development, 3(3), 5.

This is an open-access article published and distributed under the terms and conditions States unless otherwise stated. Access, citation and distribution of this article is allowed with full recognition of the authors and the source.

Authors seeking to publish with an Internationally Peer Reviewed Journals should consider https://www.ijcab.org/ by writing to the Editor at editor@ijcab.org or submitting online at https://journals.ijcab.org/journals/index.php. The articles must be quality and meet originality test. 